\title{
ISLAMIC CHARACTER EDUCATION MODEL FORMING POLITENESS IN MUHAMMADIYAH 3 WARU JUNIOR HIGHSCHOOL
}

\author{
Hidayatul Ummah \\ Universitas Muhammadiyah Sidoarjo \\ Corespondence Email: hidayahtulummah28@gmail.com
}

\begin{abstract}
Education aims to achieve the development of potential students to become human beings who believe and fear God Almighty, have noble character, are healthy, knowledgeable, capable, creative, independent, and become democratic and responsible citizens. Focus of this research is to describe the model of Islamic character education which is used as a basic form of politeness in Muhammadiyah 3 Waru Junior HighSchool. Character education curriculum needs to be embedded in a variety of character values and thoughts that can support students character as the next generation. This research method uses cooperative learning method. This research approach uses a qualitative approach. The results of this study are language politeness in Muhammadiyah 3 Waru Junior HighSchool influenced by Islamic character education models which has applied in the school environment.
\end{abstract}

Keywords: Education Model, Character Education, Islamic Character, Politeness, Spoken Language, Cooperative Learning, Qualitative Reasearch.

\section{A. INTRODUCTION}

Education as stated in UUSPN NO. 20 of 2003 is that "education aims to achieve the development of potential students to become human beings who believe and fear God Almighty, have noble character, are healthy, knowledgeable, capable, creative, independent, and become democratic and responsible citizens" . In other words, through education, it will be expected to create students who develop their potential to the maximum both intellectual (cognitive), affective (ethical, moral, spiritual, attitude, and personal), and psychomotor potential, so that all of these potentials will encourage students to become believers, devoted, noble, knowledgeable, creative, independent and responsible.

The character above is expected to be integrated in every subject, so that a character education curriculum is formed which needs to be embedded in a variety of character values and thoughts that can support the character of students as the next generation for the nation.

Yet, the results of current education only produce intellectual intelligence that causes other aspects of intelligence to be lost such as intelligence, emotional, spiritual and others that all underlie individuals in acting and behaving by considering these values. Many deviations indicate the bleak portrait of our education are low morality, insensitive to differences, the number of conflicts between tribes, cultures, moreover religious conflicts, religious conflicts not only from people of different religions but also other religions when it comes to differences in understanding it will hostility, fighting, killing each other and so on.

Based on the statement above, Islam enters as a part of education in Indonesia, is also as one of a religion which has perfect rules and system. Thus perfection involves the rules of mankind with God, humans and fellow humans, and 
humans with other creatures (nature). Therefore, Islam is called as a religion of rahmatan lil'alamin. Giving respect to other religions and fellow believers of different religions are also encouraged to respect each other. This is also enshrined in the Qur'an at:

Surah Al-Kafirun verse 6

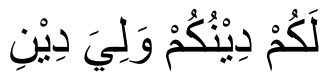

It means: "For you is your religion, and for me is my religion".

Based on the verse above, Surah Al-Kafirun always teaches us to show our respect to other religions. Since, there are many disputes between people concerning religion, the verse message provides learnings for us to create harmony of religious people, respect differences in beliefs, tolerance among fellow religious people and help one another in kindness.

Thus values are about perfect Islamic teachings, to restore knowledge, understanding and religious behavior to create harmony, harmony and modesty in life and religious life, it is necessary to create character-based Islamic values education as a model for character education empowerment by internalizing values of the truth Islam teachings and requirements with moral values.

This research is more focused on discussing the model of Islamic character education in forming politeness in Muhammadiyah 3 Waru Junior HighSchool, hopefully it can enrich science and can also be a reference for other researchers.

\section{B. RESEARCH METHOD}

This research method uses learning method that is carried out through data collection in the field, which provides an overview of Islamic character education model, which is also obtained from the observation process. Learning models are developed from deviations within student vary characteristics. Because of that, students have various personality characteristics, habits, ways of learning that are vary between individuals with each other, the learning model is not fixed only on certain models.

Learning model according to Soekamto in Trianto is a conceptual framework that describes systematic procedures in organizing learning experiences to achieve certain learning goals, and serves as a guide for learning designers and instructors in planning teaching and learning activities.

Cooperative learning ${ }^{1}$ can be interpreted as learning together, helping each other in learning and ensuring that everyone in the group can reach a predetermined goal or task. The success of learning from groups depends on the abilities and activities of group members, both individually and in groups. Cooperative learning is a series of specifically strategy that is designed to encourage students to work together during the learning process.

This research approach uses a qualitative approach. The qualitative approach is carried out by describing existing data and then followed by analyzing the Islamic character education model that occurs during the learning process in the Muhammadiyah 3 Waru Junior HighSchool environment.

This research data is in written notes that have transcribed from observations, recordings, and interviews. They are including words, phrases and sentences.

The source of data in this study is the interaction that occurs between students and students, then between students and the teacher during teaching and learning activities process (KBM) in

\footnotetext{
${ }^{1}$ Gillies, Robyn (2016). "Cooperative Learning: Review of Research and Practice" (PDF). Australian Journal of Teacher Education. 41 (3): 39-51
} 
Muhammadiyah 3 Waru Junior HighSchool, and between students and school members.

Research location is in the class when the learning process takes place, inside of the school, and other interaction places such as cafetaria, teachers office, mosque, administration office, and koperasi which are happening in the second semester of learning period from January 2019 and ends in May 2019.

\section{RESEARCH RESULTS}

Islamic character education model at Muhammadiyah 3 WARU Junior HighSchool can determine the level of politeness ${ }^{2}$ obtained by students. This is because character education itself has the basic principles of character education including: 1) human beings are creatures that are influenced by two aspects, mention in themselves to have a source of truth and from outside there are also impulses or conditions that can affect consciousness; 2) because it considers that behavior is guided by the main values as evidence of character, character education does not believe in the existence of a separation between spirit, soul, and body; 3 ) character education prioritizes the emerge of students personal awareness to be sincerely prioritize positive characters; 4) character education directs students to become ulul albab people who do not only have selfawareness but also awareness to continue for developing themselves, pay attention to their environmental problems, and improve life according to their knowledge and character; 5) a person's character is determined by what he does based on choice. Every decision has taken determines someone quality in others eyes.

Whereas the context of Islam character education or commonly has referred to be "moral" or morals in Islam.

\footnotetext{
2 Moeliono, Anton M. 1984. Santun Bahasa. Jakarta: PT Gramedia Pustaka Utama
}

It has existed since Islam itself emerged, because Prophet Muhammad was sent.

Islam on earth is to be perfect noble character, hence the Arabs were still a "savage" nation, a "ignorant" nation, and a "cultured" nation. Together with the mission of the Prophet, step by step, it has changed well until now.

This is a proof of the success of the Prophet in educating the ignorant people to become a people who have moral character, ${ }^{3}$ become "cultured" people, and "civilized" people.

Then, Islamic character is one that is sound and upright; in terms of its principles, fundamentals, and etiquette based on submission and adherence to the teaching of Islam, in obedience to Allah S.W.T and Rasulullah S.A.W.

Islamic character is also based on belief in Allah and Prophet Muhammad, which includes truthfulness, honesty, chasity, modesty, good attitude, kindness to neighbours, hastening to do good, helping people to do what is right, refraining from harming others, and other aspects of Islamic conduct.

\section{RESEARCH DISCUSSIONS}

This research focuses more on Islamic character education model at Muhammadiyah 3 WARU Junior HighSchool, which has already used Islamic character education as the school mission and vission for establish devoted, work, and achievement.

Islamic character education itself includes: 1) The flow of Aqeedah, Worship, Sharia, and Morality; 2) Insan Kamil, Ulul albab, kholifah fil-Ardl; and 3) Fitrah Concept.

\section{Aqeedah}

Aqeedah as a belief system that is manifested through the form of worship as

\footnotetext{
${ }^{3}$ Sofyan, Sauri. 2006. Pendidikan Berbahasa Santun. Bandung: PT Genesindo
} 
self-servitude to Allah by mean of Shari'a control as a medium that must be mastered while aqeedah, sharia and worship are part of worship system, which must be proven by good behavior.

Aqeedah refers to those matters which are believed in, with certainty and conviction, in one's heart and soul. In other words, Aqeedah is certainty, affirmation, confirmation, and others to worship to Allah.

Similar to Aqeedah, Worship is to show a lot of love and adoration to Allah, which is to show devotion too. Meanwhile, sharia means a well-worn path to a human life source, and a set of laws that provide a clear and straight path to fulfillment in this life and success in the hereafter. Then, morality is about good character and manner.

Aqeedah in Islam is derived from the Qur'an and Sunnah which accepted by all Muslim. In other words, It is known as Tawhid. Tawhid is the concept of monotheism in Islam. Tawhid is similar with Iman.

The importance of Aqeedah is vital in Islam. It is the pillars of the faith. Islamic aqeedah has combination between spiritual and political aqeedah. Spiritual aqeedah is one which addresses only issues of worship and ethical actions. Political aqeedah is one which addresses only the affairs of society and its governance, but offers no instruction in the areas of personal worship.

The characteristic of the Islamic aqeedah allows all aspects of the Muslims life to be ordered according to it, because it has meaning and purpose to worship Allah the one and only in the universe. That statement also mention in the Qur'an and Sunnah.

\section{Insan Kamil}

Insan kamil is the goal of Islamic education, meaning that Islamic education will produce a Muslim generation to be human beings who are able to be the successors (kholifah) of Allah on earth in the context of human function that is in line with human beings terms.

Insan Kamil also has some terms about ulul albab and kholifah fil-Ardl. Ulul Albab are the people who not only have a brain, but are gifted in knowing how to put it to its correct use. Those people do not need to have the signs of Qur'an drilled into them by constant repetition. The qualities of Ulul Albab are 1) Get bless from Allah; 2) Remember Allah at all the times and aware of Allah constant presence in their lives; 3) Pray to Allah; 4) Wise person; 5) Can fulfill their obligations to Allah in an excellent manner; 6) Extremely afraid of the Hellfire; 7) Remain patient in difficult situations in order to make Allah pleased with them; and 8) Do not nurture the attitude of retaliation.

Kholifah fil-Ardl exceeds beyond the simplicity of a successor, a vicegerent, or someone who looks after something and also beyond simply a land, the earth, and of thic world. Thus means that Allah has sent the choosen to become a mentor by chance.

\section{Fitrah Concept}

The concept of fitrah has many meanings and interpretations of Shaykh Tantawi Jawhari, which Burhanuddin cited, is expressed of fitrah concept that is based on the hadist, which means, "Every human being born in a holy state and depends on his parents the child becomes Jewish, Nasroni, or Majusi",.

Fitra or Fitrah is the state of purity and innocence Muslims believe all humans to be born with. In other words, Fitra means original disposition, natural constitution, or innate nature.

Fitrah is Tawheed (Tauhid) which is belief in the Oneness of Allah and the natural disposition upon which Allah created mankind.

There are two types of Fitrah, Fitrah Al Munazzalah and Fitrah $\mathrm{Al}$ Garizah. Fitrah Al Munazzalah is the outer 
nature that enters human beings. This Fitrah is in the form of a guide to the Qur'an and the Sunnah which is used as a control and guide for the fitrah of $\mathrm{Al}$ Garizah.

While, Fitrah Al Garizah which is namely as fitrah inherent in human beings that gives reason and is useful for developing basic human potential.

Based on Mahmud Yunus, he defines fitrah with religion and events. The point is that Islam corresponds to human events, while the incident does not change. Thus let human think with his/her sane mind, surely the human will eventually arrive at Islam. Yet, because humans are affected by their customs and relationships, they become the farthest from Islam. In short, Islam is compatible with a sane mind and perfect mind.

\section{Morality in Islam}

Morality from latin means moralis, is manner, character, and proper behaviour. Morality can be a body of standards or principles derived from a code of conduct from particular philosophy, religion, or culture, or it can derive from a standard that a person believes should be universal. Yet, religion provides different ways of dealing with moral dilemmas.

Morality in Islam encompasses the concept of righteousness, goodness, good character, and the body of moral qualities and virtues prescribed in Islamic religious texts. The principle and fundamental purpose of Islamic morality is love: love for Allah and love for Allah's creatures. The religious conception is that mankind will behave morally and treat each other in the best possible manner to please Allah.

Thus based on Qur'an and Hadist, give instruction to Muslims to adopt a morally upright character. By showing kindness to people and charity to the poor and the helpless are the most emphasized moral virtues in the Qur'an.
Concept of morality in Islam is coming as helping people who need a help, forgiving others' offenses, respecting parents and elders, filfilling promises, being kind to people and to animals, being patient in adversity, maintaining justice, being honest, and controling one's anger.

\section{Forming Politeness in Islam}

Politeness not only distinguishes a man but in addition gains popularity for Allah and makes Allah beloved in the eyes of people.

Based on Jabir Ibn Abdullah, he said that politeness with people is charity, which is involved with behaviour of people that can be produced positive results.

Politeness is part of a good attitude of the believers, and it is lowering the wing of humility to people, speaking gently, and not speaking harshly to them, which are among the best means of creating harmony.

Being polite is also being aware of our manner. Manners are a way of doing something or way of behaviour, etiquette or it could be a person's outward way of behaving toward others. Manner is very important in Islam, because it is the basis of one's success in human daily life. Conducting good manner is not easy because it takes time.

The virtues of good manners are seen in various other hadist which points to the good character that is pleasing to Allah Almighty and The Messager Prophet Muhammad S.A.W.

Good manner or Adab consists of spreading words of peace, reviving broken relationships between people, involves praying for other Muslim brothers and sisters, advising and clling each other to do good and to stop which is evil.

Good manners are about respecting parents, elders, neighbors, showing love and compassion to the young ones, visiting the sick, and abstaining from evils such as 
backbiting and slandering. Allah loves those who possess these great qualities.

Allah also says about good manner in Al-Ahzab verse 21:

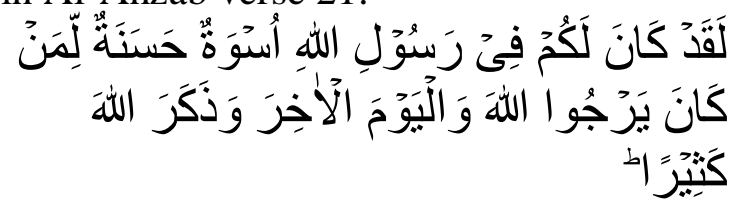

Means that:

Surely there was a good example for you in the Messenger of Allah, for all those who look forward to Allah and the Last Day and remember Allah much.

So humans all should ask Allah to make us follow the footsteps of the Prophet Muhammad and deal with the people in a way that he dealt with.

Manners are important to fulfill Humans faith and also in human social life. Being a good person can get bless and strength from Allah.

\section{Implementation of Islamic Character Education}

The implementation of Islamic character education can be pursued with the following steps: a) Designing character education through structuring the contents that will be applied to each field of study that will be studied by students; b) Exploring values that can be developed in each field of study so that they become part of character education; c) Habit and culture in each field of values emphasized in each field of study; d) Integration of all moral and religious values in social life through the practice of daily life in schools, families and communities; e) Awareness for teachers and educators to always realize character education and try to understand the education sciences for the success of Islamic character-based education; f) Continuous evaluation and control to improve the implementation of character values-based Islamic education.

The above character education implementation also forms and determines the level of politeness of students at
Muhammadiyah 3 Waru Junior HighSchool.

Modesty of Islamic perspective is a teaching impulse to make human figure realizing in order to have a complete Muslim personality (kaffah), that is, human beings who have good behavior in human view and at the same time in the sight of Allah.

The politeness of language based on Al-Qur'an is related to the manner of being polite in pronunciation, behavior, and vocabulary and adapted to the situation (condition) of the speaker, as indicated in the following paragraph:

Surah Al-Lukman verse 19

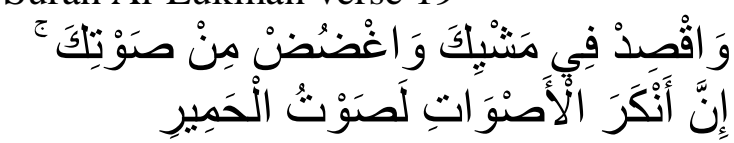

It means: "And you have to be simple in walking and soften your voice. Surely the worst voices is donkey voice".

Based on the above statement, the form of language politeness in Muhammadiyah 3 Waru Junior HighSchool is influenced by the Islamic character education model applied in the school environment. The form of politeness that has cultivated relate to language politeness and behavior.

\section{Language Politeness in Islam}

The speech of a person represents the kind of intellect and character of that person. The more refined and polite of the speech is the better thought that they have.

The major characteristic of Muslim speech is clear. It means that Muslim never respond bad words with another bad words, because Muslim always keeps peace environment. So they respond it with gentleness and goodness.

The power of life and death is in human tongue. It means that language is delivered by humans when they speak or discuss or tell someone else.

Then language is also consisting of many words. The words come out from the 
tongue that can make or break human life. A constructive word to someone who id down, he or she can lift up and can make it through the day. Yet, a destructive word to someone who is down, he or she can kill their life.

Those statement can be considered as the truth based on the Qur'an, surah AlBaqarah verse 263:

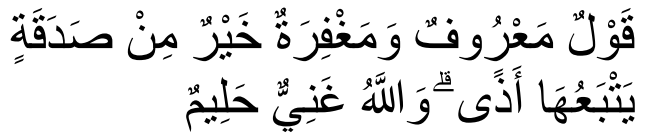

Means that: Kind speech and forgiveness are better than charity followed by injury. And Allah is Free of need and Forbearing

That means using polite language can help mankind to create peacefull environment, happiness, and comfortable life.

On the other hand, polite language is a spoken language, which is produced by human articulate sounds. That means the language is determined by the context orally and also with the cognitive of the speaker, which is related with Islam knowledges.

\section{E. CONCLUSION}

This research is expected to contribute to scientific development and can also be a reference for other researchers. The success of this research is largely determined by the Islamic character education model that is used and applied in the research location.

The Islamic character education model is needed at Muhammadiyah 3 Waru Junior HighSchool that shows aqeedah, worship, sharia, and akhlak, Insan Kamil, Ulul albab, kholifah fil-Ardl; and Fitrah Concept. The existence of this model can help to create Islamic politeness that can be used as a culture in schools.

The principle of politeness in Islam recommends that verbal communication can be born politely as wise, easy to accept or to understand, generous, humble, fit, right, honest, fair, kind, straight, smooth, polite, deserving, appreciative, solemn, optimism, beautiful, pleasant, logical, bright, precise, touching, harmonious, impressive, calm, effective, soft, gentle, humble and sympathetic.

By using polite language, it does not offend other individuals or groups, language that reflects the logic, logic, thinking and functioning of language as a tool, to work together will form harmonious social relations. Words that are carefully chosen and pay attention to politeness values can have a positive influence on the mood of the reader or listener.

Through the language, all language components have the opportunity to establish relationships and work together. For this reason, it is necessary to develop a language attitude that contains politeness, meticulous, and economical.

Then language is also consisting of many words. The words come out from the tongue that can make or break human life. A constructive word to someone who id down, he or she can lift up and can make it through the day. Yet, a destructive word to someone who is down, he or she can kill their life, because the power of life and death is in human tongue. It means that language is delivered by humans when they speak or discuss or tell someone else.

Being polite is an obligatory in Islam. It is based on Al-Qur'an. Besides, Islam is also polite religion. It shows about mantaning good relationship has to be a main priority.

The politeness of language based on Al-Qur'an is related to the manner of being polite in pronunciation, behavior, and vocabulary and adapted to the situation (condition) of the speaker.

Therefore, students of Muhammadiyah 3 Waru Junior Highschool must be improve their language and add huge polite about addressing, saying 
somethine, and asking to someone else, especially teachers.

Speaking polite language can create peacefull environment, happiness, and comfortable learning in Muhammadiyah 3 Waru Junior HighSchool. So there is not any missunderstanding between students and teachers. Living in harmony is the priority life which is established for Muslims based on Al-Qur'an and Hadists.

Being polite and good manner students are a part of Islamic identity, especially in Islam school.

Therefore, we have to take care Islam custom and culture based on AlQur'an and Hadist, for generation to generation and also to maintain morality in social life nowadays.

\section{REFERENCES}

\section{Books}

Al-Qur'an dan Terjemahannya.1989 Departemen Agama RI.

Alwasilah, A, Chaedar.2000. Perspektif Pengajaran Bahasa Inggris di Indonesia dalam Konteks Persaingan Global. Bandung: Andira

Geertz, C.1972. Linguistic Etiqutte Reading in the Sociology of Language. Paris:

Liliweri, Alo. 1991. Komunikasi Antar Pribadi. Bandumg: Citra Aditya Bakti

Moeliono, Anton M. 1984. Santun Bahasa. Jakarta: PT Gramedia Pustaka Utama.

Sofyan, Sauri. 2006. Pendidikan Berbahasa Santun. Bandung: PT Genesindo.

\section{Papers}

Dahlan, M.D. 2001. Nilai Al-Qur'an dalam Memelihara Tutur Kata. Makalah Tanggal 4 Desember 2001.

Sahib, Muzdalifah. 2000. The Use of Polite Expression in English and Makassare (A CrossCultural Study).

A Thesis. Makassar: Hasanuddin University.

\section{Article Journals}

Gillies, Robyn (2016). "Cooperative Learning: Review of Research and Practice" (PDF). Australian Journal of Teacher Education. 41 (3): 39-51

Muhammad Hambal. 2015. "Deresan" Program the Mastery of ArabicClassic Book at Pondok Pesantren Karangasem Lamongan East Java Indonesia. Journal of Social Sciences and Humanities, Vol. 1, No. 2, pp. 125-130

Hasnan, I. 1993. Komunikasi menurut Pendekatan Islam. Jurnal Komunikasi. I (1) 35-56.

Rakhmat, J.1993. "Audiential”. Prinsipprinsip Komunikasi menurut AlQur'an: Jurnal Komunikasi. I (1). 3556

Saryono, D dan Soedjito.1990. Berbahasa Secara Pragmatik. Jurnal Vokal. 02.1.2007.

Supardo, Susilo.2003. Potensi Bahasa Indonesia Sebagai Media Transformasi Budaya. Makalah dalam Pertemuan Ilmiah Bahasa Dan Sastra Indonesia (PIBSI).Maunton 